\title{
The first outdoor find of an American snail Zonitoides arboreus (Say, 1816) from the Czech Republic
}

\author{
LIBOR DVOŘÁK ${ }^{1} \&$ JIŘí KUPKA ${ }^{2}$ \\ ${ }^{1}$ Šumava National Park Administration, Dept. of Science and Research, Sušická 399, CZ-34192 Kašperské Hory, Czech Republic, e-mail: \\ libor.dvorak@npsumava.cz \\ ${ }^{2}$ Institute of Environmental Engineering, Faculty of Mining and Geology, V̌̌B - Technical University of Ostrava, 17. listopadu 15/2172, CZ- \\ 70833 Ostrava-Poruba, e-mail: jiri.kupka@vsb.cz
}

DVOŘÁK L. \& KUPKA L., 2007: The first outdoor find of an American snail Zonitoides arboreus (Say, 1816) from the Czech Republic. - Malacologica Bohemoslovaca, 6: 1-2. Online serial at $<$ http://mollusca.sav.sk> 9-Jan-2007.

The first outdoor record of the pulmonate land snail Zonitoides arboreus in the Czech Republic is presented. Our living population has survived the complete destruction of greenhouses and has been living in the open at the locality for several years. The Czech Republic is the fourth European mainland country with outdoor occurrence of this species.

\section{Introduction}

Zonitoides arboreus (Say) (Fig. 1) is a snail species native to much of North America (PILSBRY 1946, HUBRICHT 1985). It is one of the commonest species in greenhouses in the Czech Republic (see HoRSÁK et al. 2004 for review). No outdoor find was known from the Czech Republic until now.

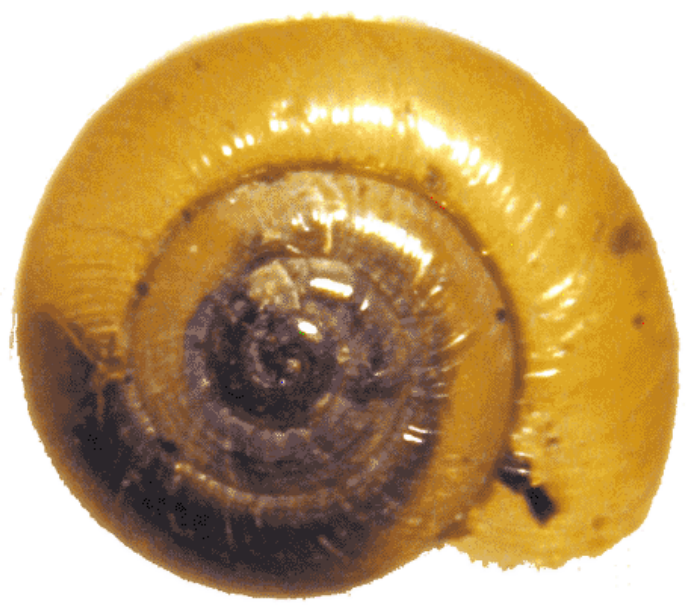

\section{Locality}

Havírov - Prostřední Suchá, area with destroyed greenhouses, $49^{\circ} 47^{\prime} 29.16^{\prime \prime} \mathrm{N}, 18^{\circ} 26^{\prime} 30.13^{\prime \prime} \mathrm{E}$, code of the faunistic mapping grid system $6276 \mathrm{~B}, 25$ October 2006, L. Dvořák et J. Kupka leg., det. et coll. Photo of one specimen see at Fig. 1.

Fig. 1. Zonitoides arboreus, living specimen from locality Prostřední Suchá. Photo J. Kupka. 


\section{Results and discussion}

The locality was visited in 1968 by MÁCHA (1971) who found several typical greenhouses species in the greenhouses of Prostřední Suchá. Zonitoides arboreus was one of the commonest species here. The greenhouses were commercially used up to 1993, when the owner, fa. OKD Rekultivace a.s., stopped their activities in the greenhouses. Between 1993-1998, several greenhouses were used by other people. The area has been abandoned since 1998. In 2006, when mollusc research was done, the greenhouses were already completely destroyed and typical ruderal vegetation was present in the whole area (Fig. 2).

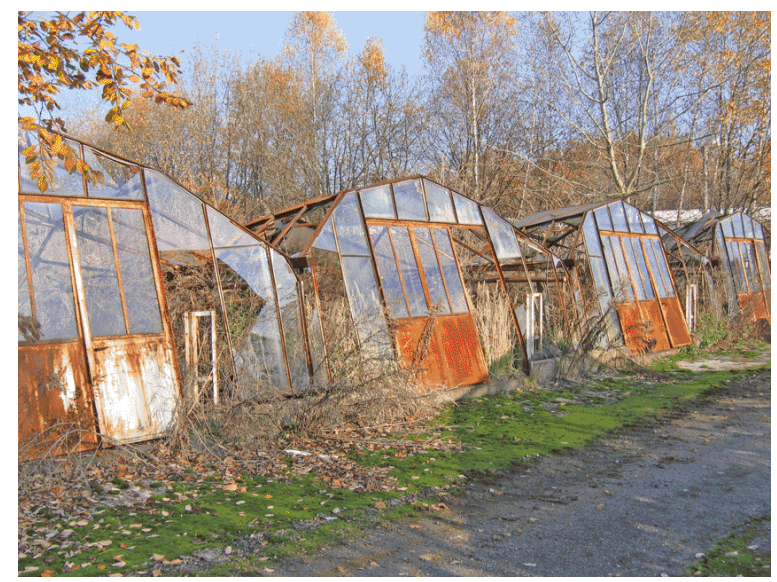

Fig. 2. Locality of Zonitoides arboreus in Prostřední Suchá. Photo J. Kupka.

The molluscan assemblage found on $25^{\text {th }}$ Oct 2006 is follows:

Cochlicopa lubrica (O. F. Müller, 1774)

Vallonia pulchella (O. F. Müller, 1774)

Alinda biplicata (Montagu, 1803)

Oxyloma elegans (Risso, 1826)

Discus rotundatus (O. F. Müller, 1774)

Zonitoides arboreus (Say, 1816)

Vitrina pellucida (O. F. Müller, 1774)

Eucobresia nivalis (Dumont et Mortillet, 1854)

Semilimax semilimax (J. Férussac, 1802)

Perpolita hammonis (Ström, 1765)

Oxychilus draparnaudi (Beck, 1837)

Limax maximus Linnaeus, 1758

Deroceras reticulatum (O. F. Müller, 1774)

Arion distinctus Mabille, 1868

Arion lusitanicus Mabille, 1868

Fruticicola fruticum (O. F. Müller, 1774)

Trochulus hispidus (Linnaeus, 1758)

Monachoides incarnatus (O. F. Müller, 1774)

Cepaea hortensis (O. F. Müller, 1774)

As can be seen from the list of species, Z. arboreus is the only typical greenhouse species, which has sur- vived the greenhouses' destruction and remains living in this area up to the present. This find is the first outdoor occurrence of $Z$. arboreus within the Czech Republic.

Probably the first outdoor European find of $Z$. arboreus became from Sweden; this species has several outdoor records here at present (VON PROSCHWITZ 2003). Several outdoor finds from secondary stands such as botanical gardens or arboreta are known from Hungary (FEHÉR \& GUBÁNYI 2001). The last find is from a ruderal site near a cemetery in MecklenburgVorpommern, Germany (JUEG \& VON PROSCHWITZ 2003). This find is from a very interesting assemblage with sensitive species of the open landscape as well as non-native and ruderal species.

Judging by these other European occurrences, the Czech find is not surprising, but it is expectable. The major part of Europe lays on similar latitudes as sites with Z. arboreus in North America (PILSBRY 1946, HUBRICHT 1985). Similar climatic conditions are suitable for additional spreading of this species throughout Europe, mainly for populations originating from the latitudes with the mild climate.

\section{Conclusions}

The Czech Republic is the fourth mainland European country with outdoor occurrence of Zonitoides arboreus. As in Sweden, Hungary, and Germany, Z. arboreus was found on a disturbed secondary stand.

\section{References}

FEHÉR Z. \& GUBÁNYI A., 2001: A magyarországi puhatestüek elterjedése. Az MTM (Magyar Természettudományi Múzeum) puhatestü-gyüjteményének katalógusa [The distribution of Hungarian molluscs. The catalogue of the mollusca collection of the Hungarian Natural History Museum]. - MTM, Budapest, 466 pp.

HorsÁK M., DVOŘÁK L. \& JUŘIČKOvÁ L., 2004: Gastropods of greenhouses of the Czech Republic: current stage of research. - Malacological Newsletter, 22: 141-147.

HuBricht L., 1985. The distribution of the native land mollusks of the eastern United States. - Fieldiana, Zoology, New Series, 24: 1-191.

JUEG U. \& VON Proschwitz T., 2003: Ein Freilandfund von Zonitoides arboreus (Say 1816) im Landkreis Ludwigslust (Mecklenburg-Vorpommern). - Mitt. dtsch. malakozool. Ges., 69/70: 15-19.

MÁCHA S., 1971: Kulturní vlivy na faunu měkkýšů [Cultural impact on malacofauna]. - Čas. Slez. Muzea Opava, ser. A, 20: 121-134.

PILSBRY H.A., 1946: Land mollusca of North America (North of Mexico). Vol II. Part I. - Acad. Nat. Sci., Philadelphia, 520 pp.

VON Proschwitz T., 2003: Faunistiskt nytt 2002 - snäckor, sniglar och musslor [Faunistical news from the Natural History Museum, Göteborg 2002 - snails, slugs and mussels]. - Göteborgs naturhistoriska musuem Årstyck, 2003: 25-42. 